\title{
DiURNAL VARIATION OF AMMONIA EMISSION IN Pig Fattening Facilitties
}

\author{
OCEPEK, M.; BERK, P.; RAKUN, J.; \\ JANZEKOVIC, M. \& SKORJANC, D.
}

Abstract: The objective of the present study was to determine diurnal variation of ammonia emission in pig fattening facilities. Measurements were carried in fattening period from 11 weeks of pigs' age to 26 weeks of pigs' age. The performance characteristics of daily gain, body weight and feed consumption were evaluated. In addition, excretory behaviour was evaluated in first (11-22 weeks) and last part (22-26 weeks) of the fattening periods. Microclimatic conditions and ammonia concentration were observed using a monitoring system. In first 11 weeks (11-22 week), ammonia

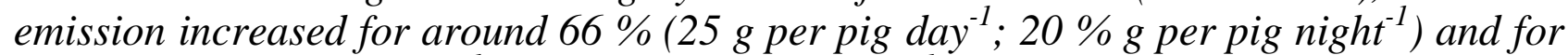
$75 \%$ (25 g per pig day ${ }^{-1} ; 20 \% \mathrm{~g}$ per pig night ${ }^{-1}$ ) in whole fattening period (11-26 weeks). Such differences in ammonia emission may be explained as a consequence of change excretory behaviour of the pigs, which is a result of the increased pigs' body weight. Higher differences in ammonia emission per pig, during day and night time were observed in first part (11-22 weeks) of fattening period (25\%). In the last part (22-26 weeks) of fattening period, diurnal variation of ammonia emission decreased to $17 \%$ and was lowest in last week's (5\%). This could be explained with pigs' change activity pattern (day/night), especially, pigs with lower status of social hierarchy.

Key words: pigs, diurnal variation, ammonia emissions, microclimatic conditions
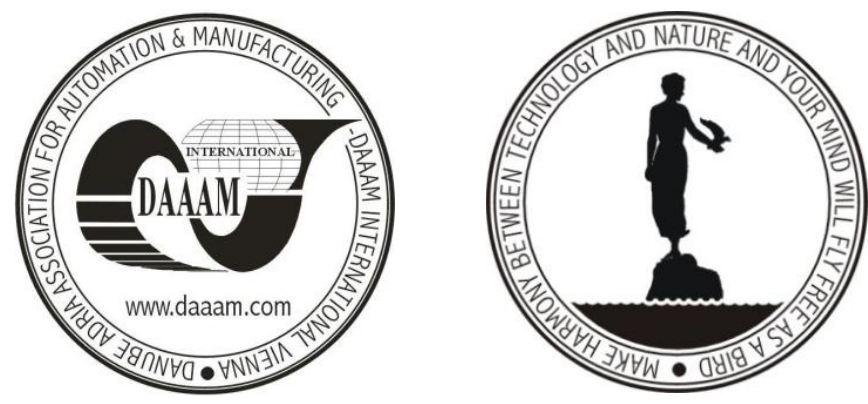

Authors' data: Msc. Ocepek, M[arko]; Bs. Elect. Eng. Berk, P[eter]; Assist. Prof. Rakun, J[urij]; Assist. Prof. Janzekovic, M[arjan]; Assoc. Prof. Skorjanc, D[ejan]; University of Maribor, Faculty of Agriculture and Life Sciences, Pivola 10, SI-2311, Hoce, Slovenia, marko.ocepek@uni-mb.si, peter.berk@uni-mb.si, jurij.rakun@unimb.si,marjan.janzekovic@uni-mb.si,dejan.skorjanc@uni-mb.si

This Publication has to be referred as: Ocepek, M[arko]; Berk, P[eter]; Rakun, J[urij]; Janzekovic, M[arjan] \& Skorjanc, D[ejan] (2012). Diurnal Variation of Ammonia Emission in Pig Fattening Facilities, Chapter 10 in DAAAM International Scientific Book 2012, pp. 107-116, B. Katalinic (Ed.), Published by DAAAM International, ISBN 978-3-901509-86-5, ISSN 1726-9687, Vienna, Austria

DOI: $10.2507 /$ daaam.scibook.2012.10 
Ocepek, M.; Berk, P.; Rakun, J.; Janzekovic, M. \& Skorjanc, D.: Diurnal Variation ...

\section{Introduction}

Ammonia emissions from pig houses represent a major problem to the environment (Aarnink et al., 1996). Most of these emissions are produced in fattening facilities (Ni et al., 1999). This is due to the increased feeding and manure production as the pigs grow (Philippe et al., 2007). The main source of ammonia emissions represent wetted pen area with urine (Aarnink et al., 2006). Proportion of wetted floor is influenced with excretory behaviour of the pigs, which is associated to the pigs' preferences to the lying pen area (Aarnink et al., 1996). It is well established that pigs prefer to lie on a solid floor (Aarnink et al., 1997), and excrete on the slatted floor (Aarnink et al., 1997). However, very little is known how pig behaviour affect diurnal variation (day/night ratio) in ammonia emission. With such knowledge we could easier understand how ammonia emission is related to pig facilities and how could be lowered.

Therefore, the aim of the present study was to compare the diurnal variation ammonia emissions in the first part (11-22 weeks) and last part (22-26 weeks) of the fattening period. In addition, microclimatic condition, fattening characteristics, as well as the behaviour of pigs with respect to urination were determined.

\section{Materials and Methods}

\subsection{Animal and feed}

All procedures and animal treatments were according to the Slovenian legislation on animal protection (Animal Law, 2007). Group of 33 pigs at the age of 11 week [LandracexLarge White dams and LandracexPietrain sires] were divided into 3 homogeneous groups according to the body weight and therefore allocated to one of the three replicates (pens) inside the pig house. The experiment was conducted in September and lasted until slaughter (December) when pigs achieved 26 weeks of age. Feed intake was measured daily, while drinking water was available ad libitum. The pigs were weighed individually at the beginning of the research (11 weeks of age), and subsequently at 22 weeks and 26 weeks of age. Daily gains were calculated using the data on body weight and age at weighing for the whole experimental period and for the periods between sequential weight measurements. Feed intake was recorded per pen and divided by the number of pigs to give the daily intake per pig.

\subsection{Animal facilities}

The investigation was conducted in the Pig Research Centre at Faculty of Agriculture and Life Sciences (University of Maribor, Slovenia). The layout of the pens is shown in Figs 1. Pens size was $7.9 \mathrm{~m}^{2}$. Pen floor consisted of two thirds solid concrete floor and one third slatted floor (Fig. 1). Fatteners were fed in a feeder $(0.33$ per pig). Drinkers were positioned above the slatted floor. 
Fig. 1. Layout of the pens

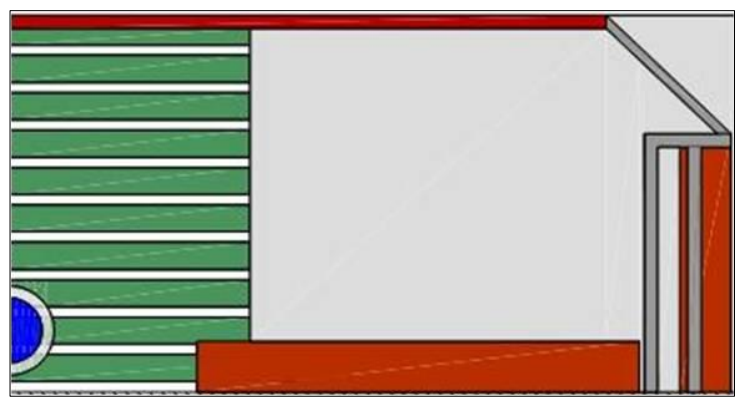

In fattening room a combination of natural and artificial lights was used. Light intensity was above 40 lux for 8 hours per day, and it was in agreement with the law for animal protection (Animal law, 2007).

In the experiment, a negative pressure ventilation system with a diffuse inlet ceiling unit was used. The system had one central exhaust unit in fattening room, with the ventilator located at the roof of the house. In this ventilation system, fresh air came into the attic through the side inlet units and into the room through diffuse ceiling inlets due to the negative pressure.

\subsection{Microclimatic monitoring system}

Echo monitoring system (Echo d.o.o., Slovenia) was used to measures ammonia concentrations, temperature, air velocity, relative humidity, barometric pressure, and light intensity. All parameters were stored on an internal hard drive for each day separately. The Echo monitoring system was placed close to exhaust outlets units. Recorded values could be transferred through an RS-232 connection to the computer and could be monitored subsequently. Sensors in monitoring device were calibrated manually each morning. For that purposes, monitoring device was placed in room with clean, fresh air. With pressing on the button on the control panel, calibration sets oxygen sensor to $21 \%$, while other gases to zero ppm.

\subsection{Ammonia emission measurements}

Ammonia concentration and emission were measured using an electrochemical galvanic cell. The measuring range was $0-100 \mathrm{ppm}$, with measurement accuracy of 1 $\mathrm{ppm}$. The level of ammonia was determined with a sensor fitted with combined metal and air electrodes.

To convert ammonia concentration from parts per million to $\mathrm{mg} \mathrm{NH}_{3} \mathrm{~m}^{-3}$ equation 1 was used:

$$
\mathrm{p}=\left(\frac{\mathrm{M}}{22.4}\right) \times\left(\frac{\mathrm{To} \times \mathrm{P}}{\mathrm{Po} \times \mathrm{T}}\right)
$$

Where $\mathrm{M}$ is for ammonia molecular mass, while To, Po, $\mathrm{T}$ and $\mathrm{P}$ stand for normal temperature $(-273 \mathrm{~K})$, normal pressure $\left(1.03 \mathrm{~kg} / \mathrm{cm}^{2}\right)$, measured temperature and measured pressure, respectively. Ammonia emission was calculated per pig and per $\mathrm{m}^{2}$. Therefore, monitoring device placed near exhaust unit measured beside ammonia concentration, also air flow every 5 minute. To analyze diurnal variation of 
Ocepek, M.; Berk, P.; Rakun, J.; Janzekovic, M. \& Skorjanc, D.: Diurnal Variation ...

12 hour (6:00 am to $6: 00 \mathrm{pm})$ of day time and 12 hours $(6: 00 \mathrm{pm}$ to $6: 00 \mathrm{am})$ of night time were compared.

\subsection{Air velocity, temperature and relative humidity}

Air velocity was measured using a thermal thin-layered detector. The detector was placed at pig height to measure the airflow. The air velocity measuring range was $0.0-1.0 \mathrm{~m} / \mathrm{s}$, with a measurement accuracy of $0.04 \mathrm{~m} / \mathrm{s}$. Relative humidity was measured using a semiconductor sensor with a measuring range of $0-100 \%$ and accuracy of $\pm 1 \%$. Temperature was measured with resistance thermometers $(\mathrm{Pt}$ 100), with a range of $-40{ }^{\circ} \mathrm{C}$ to $+60{ }^{\circ} \mathrm{C}$ and accuracy of $1{ }^{\circ} \mathrm{C}$. Sensors for relative humidity and temperature were located in the mid-lower side, while the air velocity detector was at the bottom of the machine.

\subsection{Statistical analysis}

Analysis of variance was performed with the GLM procedure of SPSS 20 in order to evaluate the effect of diurnal variation in ammonia emission in fattening period. The parameters tested were body weight, average daily gain, feed intake separately for first part of fattening period (11-22 weeks) and last part of fattening period (22-26 weeks). Microclimatic condition and ammonia emission were also compared. Pig urination behaviour in first and last part of fattening period were determined by the Chi-square test. Statistical differences expressed in Tables and Figures are as $*(\mathrm{P} \leq 0.05),{ }^{* *}(\mathrm{P}<0.01), * * *(\mathrm{P}<0.001)$.

\section{Results with discussion}

\subsection{Growth and fattening pattern}

Table 1 represents' the feed consumption, and daily gain. When comparing first period (11 week to 22 week) to last fattening period (22-26 weeks) significant difference $(\mathrm{P} \leq 0.001)$ were observed. With increasing feed intake, daily gain decreased. Decreased pigs' daily gain is normal appearance at the end of the fattening period. This is a consequence of feed restriction. Feeding restriction at the end of the fattening period can be applied up to $35 \%$ when comparing to ad libitum feed intake (Lebret, 2008). Thereby growth rate of pigs can be reduced up to $27 \%$ (Quiniou et al., 1995; Lebret et al., 2001). In the present study with $30 \%$ of feed restriction in last period, $10 \%$ of the reduction in daily gain was observed. Such reduction is recommended, especially due to higher protein deposition rate as well as less fat tissue deposition in the pigs' carcass (Ellis et al., 1996; Wood et al., 1996; Lebret et al., 2001). 


\begin{tabular}{|l|l|l|l|c|}
\hline Item & & $\begin{array}{l}11-22 \\
\text { WEEKS }\end{array}$ & $\begin{array}{l}22-26 \\
\text { WEEKS }\end{array}$ & $P$ \\
\hline Feed intake & & & & \\
\hline kg day $^{-1}$ & & 1,89 & 2,20 & $* * *$ \\
\hline Daily gain & & & \\
\hline \multicolumn{2}{|r|}{ g day $^{-1}$} & 703 & 633 & $* * *$ \\
\hline
\end{tabular}

Tab. 1. Daily gain, body weight and feed intake in different periods

Pigs' average live body weight at moving in fattening room (11 week) was $22.0 \mathrm{~kg}$ (Fig. 2). In the first part of fattening period (11-22 weeks) pigs increased live body weight in amount of $54.6 \mathrm{~kg}$, while in the last fattening period (22-26 weeks) pigs additionally increased body weight in amount of $18.0 \mathrm{~kg}$. Consequently, at the end of fattening period pigs average live body weight was $94.2 \mathrm{~kg}$ (Fig. 2).

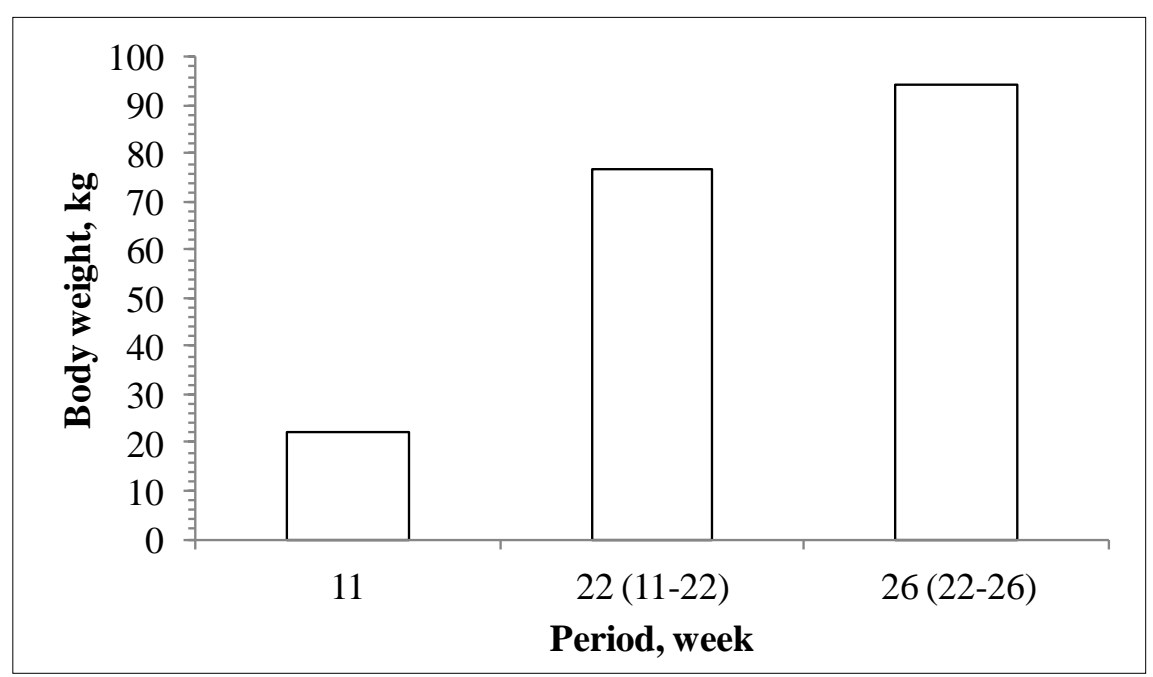

Fig. 2. Pigs average live body weight during research

\subsection{Microclimatic condition}

The mean values and standard deviations of microclimate conditions are presented in Table 2. When comparing first (11-22 weeks) and last part of fattening period (22-26 weeks), significant difference was observed in ambient temperature. The average ambient temperature in first part of the fattening period exceeded for 9 $\%$ when compare to an average ambient temperature in last part of the fattening period. Additionally, higher standard deviances of ambient temperature were recorded in first part of fattening period. In September (beginning of the fattening period) indoor ambient temperature was around $22{ }^{\circ} \mathrm{C}$ and was reduced in October to $18.5^{\circ} \mathrm{C}$. This reduction was probably related to lower outdoor temperatures, which is normal temperature reduction during autumn.

Relative air humidity was between $63 \%$ and $66 \%$, and these values met regulations for animal care (60-80\%) (Animal law, 2007). No significant differences in relative air humidity were observed (Table 2). In first and last part of fattening period, similar light intensity was provided. However, significant differences in light 
intensity were found when comparing the diurnal variation (day and night time). During the day, light intensity was significantly higher by approximately $87 \%$ (P $\leq$ 0.001 ) in comparison to night time. This was achieved with artificial light and additional source from natural light available during day time.

No differences in air velocity in fattening period were observed (Table 2). It has been reported that the optimal air velocity at pig height should be 0.15 to $0.28 \mathrm{~m} / \mathrm{s}$ in the fattening period, if optimal temperatures for fattening pigs are provided (Verstegen et al., 1987). In present study optimal ambient temperature were ensured according to previous reports (McFarlane \& Cunningham, 1993; Olsen et al., 2001). No other significant differences in microclimatic condition were observed when analyzing diurnal variation (day/night ratio). Nevertheless, ammonia emissions have been significantly influenced with day/night ratio as well as fattening period.

\begin{tabular}{|l|c|c|c|c|c|c|}
\hline$(\mathrm{N}=7.633)$ & $\begin{array}{c}\text { Weeks } \\
11-22\end{array}$ & $\begin{array}{c}\text { Weeks } \\
22-26\end{array}$ & $P$ & $\begin{array}{c}\text { Day } \\
11-26\end{array}$ & $\begin{array}{c}\text { Night } \\
11-26\end{array}$ & $P$ \\
\hline Ambient temperature, ${ }^{\circ} \mathrm{C}$ & $20.3 \pm 2.0$ & $18.4 \pm 0.6$ & $* * *$ & $19.8 \pm 1.9$ & $19.8 \pm 1.9$ & $\mathrm{~ns}$ \\
\hline Relative humidity, \% & $66 \pm 3$ & $63 \pm 4$ & $\mathrm{~ns}$ & $61 \pm 2$ & $63 \pm 3$ & $\mathrm{~ns}$ \\
\hline Pressure, bar & $987 \pm 7$ & $993 \pm 00$ & $\mathrm{~ns}$ & $988 \pm 7$ & $989 \pm 7$ & $\mathrm{~ns}$ \\
\hline Air velocity, $\mathrm{m} / \mathrm{s}$ & $0.28 \pm 0.2$ & $0.29 \pm 0.2$ & $\mathrm{~ns}$ & $0.29 \pm 0.0$ & $0.28 \pm 0.0$ & $\mathrm{~ns}$ \\
\hline Light intensity, lux & $71 \pm 55$ & $67 \pm 59$ & $\mathrm{~ns}$ & $118 \pm 42$ & $16 \pm 8$ & $* * *$ \\
\hline Ammonia emission, g day ${ }^{-1}$ pig $^{-1}$ & $14.1 \pm 5.6$ & $26.2 \pm 5.5$ & $* * *$ & $19.3 \pm 7.6$ & $15.3 \pm 7.1$ & $* * *$ \\
\hline
\end{tabular}

Tab. 2. Means and standard deviations of ammonia emission and microclimatic condition in fattening pig room throughout the experiment

\subsection{Ammonia emission}

Gradually increased ammonia emission per pig was observed during first and last part of fattening period (Fig. 2). At the beginning (11 week) ammonia emission per pig was $8.4 \mathrm{~g}$ during day and $6.7 \mathrm{~g}$ in night time. In first 11 weeks (11-22 week), ammonia emission increased for around $66 \%$ (day $25 \mathrm{~g}_{\text {per pig day }}{ }^{-1}$; night $20 \% \mathrm{~g}$ per pig night $\left.{ }^{-1}\right)$ and for $75 \%$ (25 g per pig day $\left.{ }^{-1} ; 20 \% \mathrm{~g}_{\text {per pig night }}^{-1}\right)$ in whole fattening period (11-26 weeks). Increased values of ammonia emission at the end of the fattening period were observed in previous studies when analyzing excretory behaviour. Urine puddles are an important source of ammonia emission caused by urea degradation by the enzyme urease (Ivanova-Peneva et al., 2008). Therefore, main source of ammonia emissions are urine pools on solid concrete floors (Aarnink et al., 1997; Groenestein et al., 2007). On slatted floors, urine drains into the pit as well as entering into the pores of the slats (Groenestein et al., 2007). Nevertheless, ammonia emissions from slatted floor are still not negligible (Aarnink et al., 1996). In the present study, pigs urinated significantly more frequently on slatted floors in first part of fattening period (Fig. 3). Altered behaviour was observed in last part of fattening period, when pigs significantly more frequently urinate on solid floors in comparison to first fattening period (Fig. 3). Such behaviour is perused by higher ammonia emissions (Aarnink et al., 2006). 


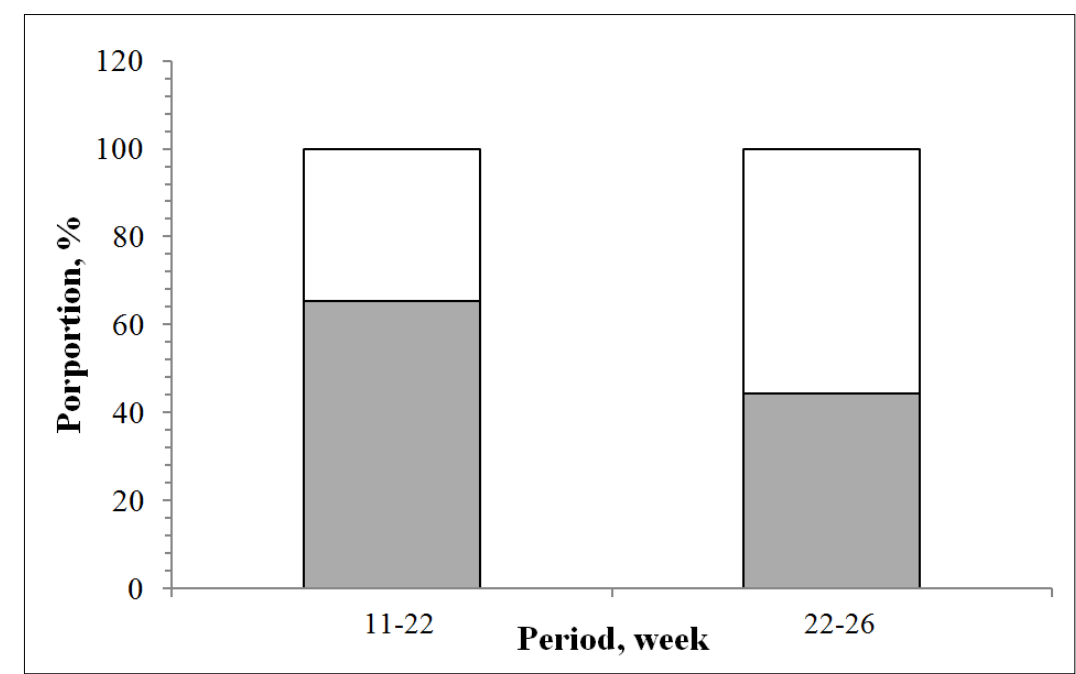

Fig. 3. Urination frequency on solid and slatted floor ( $\square$ - solid floor, $\square$ - slatted floor)

From present study it could be concluded that the amount of the excretion on the solid floor increased with increasing pigs' body weight. The main reason for increased urination on solid floor at the end of the fattening period could be the lack of space for the pigs as observed by Huynh et al. (2005).

Ammonia emission shows also the diurnal variations with day/night ratio (Fig. 2). Ammonia emission were higher for around $23 \%$ during day time when compare to night time. This could be explained with animal activity. In previous studies has been confirmed that ammonia emissions are highly correlated with feeding and excretory behaviour (Groenestein et al., 2003; de Sousa \& Pedersen, 2004; Guarino et al., 2008). Guarino et al. (2008) observed that most pigs excreted $1 \mathrm{~h}$ or $2 \mathrm{~h}$ after feeding and Aarnink et al. (1996) found linear relationships between urinating frequency and ammonia emissions. In present study was analyzed also the difference in diurnal variation during fattening period. Higher differences in ammonia emission per pig, during day and night time were observed in first part of fattening period (25 $\%$ ). In the last part of fattening period, diurnal variation of ammonia emission decreased. Average ammonia day/night difference was only $17 \%$, with lowest variation observed in last two week's (5\%). From our results could be concluded that with increasing body weight the diurnal variations decreased. This could be explained with pigs' change urinate pattern (day/night). Pigs with lower status of social hierarchy avoid contacts at feeder, drinker (Weary et al., 2008). Therefore, possible explanation is that pigs with low hierarchy status eat, drink and consequently urinate more frequently also in night time, when a lack in space at the end of the fattening period is observed. 


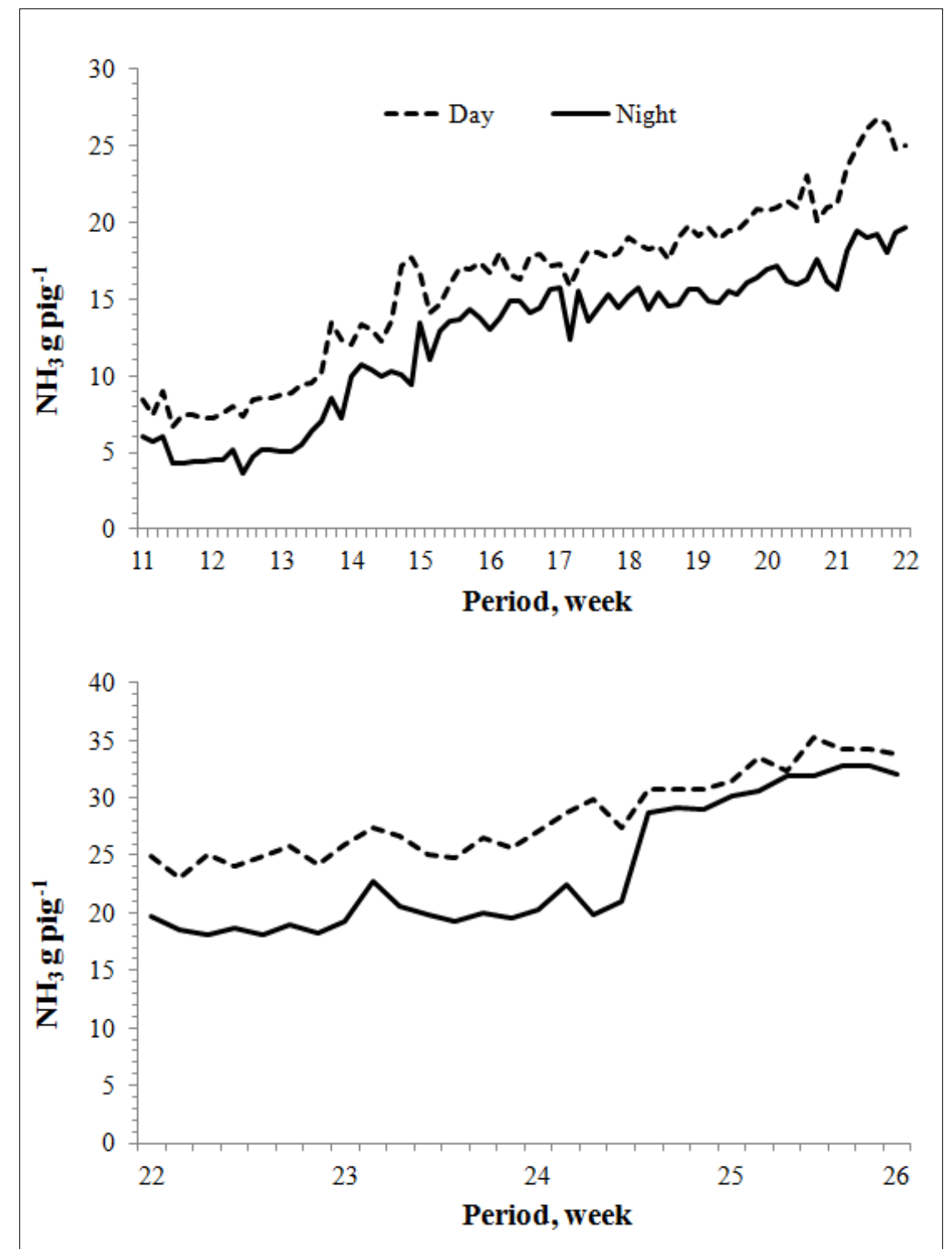

Fig. 4. Diurnal variation of ammonia emission from 11 weeks of pigs' age to 26 week of pigs' age

\section{Conclusions}

Studying the diurnal variation in ammonia emissions showed differences in first (11-22 weeks) and last part (22-26 weeks) of the fattening period. In whole period, ammonia emission has gradually increased. Such increased value of ammonia emission is a consequence of change excretory behaviour of the pigs, while change behaviour is a resulted of the increased pigs' body weight. However, ammonia emission also shows differences in day/night ratio. During day time ammonia emission increased in comparison to night time. This has been related to pigs' activity (drinking, feeding, urinations, and defecation). However, in last week's day/night ration has decreased, which has been a result of the increased pigs' body weight. Therefore, lack of space forced pigs to change their activity (drinking, feeding, excretory behavioural) especially pigs with lower social hierarchy. 
From present study it could be concluded that higher ammonia emission are produced during day time. Consequently, floor cleaning in the afternoon (instead in the morning) would be preferred. With such simple solution we could additionally contribute to the reduction of the ammonia emissions in pig fattening facilities.

\section{References}

Aarnink, A. J. A.; Schrama, J. W.; Verheijen, R. J. E.; \& Stefanowska, J. (2001). Pen fouling in pig houses affected by temperature. ASAE $6^{\text {th }}$ International Symposium (21-23 May 2001), Louisville, Kentucky, USA (Richard R. Stowell, Ray Bucklin and Robert W. Bottcher, eds), pp.180-186

Aarnink, A. J. A.; Swierstra, D.; van den Berg, A. J. \& Speelman, L. (1997). Effect of type of slatted floor and degree of fouling of solid floor on ammonia emission rates from fattening piggeries. Journal of Agricultural Engineering Research, Vol.66, No.2, pp.93-102, ISSN 1095-9246

Aarnink, A. J. A.; van den Berg, A. J.; Keen, A.; Hoeksma, P.; \& Verstegen, M. W. A. (1996). Effect of slatted floor area on ammonia emission and on the excretory and lying behaviour of growing pigs. Journal of Agricultural Engineering Research, Vol.64, pp.299-310, ISSN 1095-9246

Aarnink, A.J.A.; Schrama, J.W.; Heetkamp, M.J.W.; Stefanowska, J.; \& Huynh, T.T.T. (2006). Temperature and body weight affect fouling of pig pens. Journal of Animal Science, Vol.84, pp.2224-2231, ISSN 1525-3163

de Sousa, P.; \& Pedersen, S. (2004). Ammonia emission from fattening pig houses in relation to animal activity and carbon dioxide production. Agricultural Engineering International: CIGR E-journal VI, Manuscript BC04 003.

Ellis, M.; Webb, A. J.; Avery, P. J.; \& Brown, I. (1996). The influence of terminal sire genotype, sex, slaughter weight, feeding regime and slaughter-house on growth performance and carcass and meat quality in pigs and on the organoleptic properties of fresh pork. Animal Science Vol.62, pp.521-530, ISSN 1525-3163

Groenestein, C. M.; Hendriks, M.; \& den Hartog, L. A. (2003). Effect of feeding schedule on ammonia emission from individual and group-housing systems for sows. Biosystems Engineering, Vol.85, pp.79-85, ISSN: 1615-7605

Groenestein, C. M.; Monteny, G. J.; Aarnink, A. J. A.; \& Metz, J. H. M. (2007). Effect of urinations on the ammonia emission from group-housing systems for sows with straw bedding: model assessment. Biosystems Engineering, Vol.97, pp.89-98, ISSN: 1615-7605

Guarino, M.; Costa, A.; \& Porro, M. (2008). Photocatalytic TiO2 coating - to reduce ammonia and greenhouse gases concentration and emission from animal husbandries. Bioresource Technology, Vol.99, pp.2650-2658, ISSN: 09608524

Huynh, T. T. T.; Aarnink, A. J. A.; Gerrits, W. J. J.; Heetkamp, M. J. H.; Canh, T. T.; Spoolder, H. A. M.; Kemp, B.; \& Verstegen, M. W. A. (2005). Thermal 
Ocepek, M.; Berk, P.; Rakun, J.; Janzekovic, M. \& Skorjanc, D.: Diurnal Variation ...

behaviour of growing pigs in response to high temperature and humidity. Applied Animal Behaviour Science, Vol.91, pp.1-16, ISSN 0168-1591

Ivanova-Peneva, S. G.; Aarnink, A. J. A.; \& Verstegen, M. V. A. (2008). Ammonia emissions from organic housing systems with fattening pigs. Biosystems Engineering, Vol.99, pp.412-422, ISSN: 1615-7605

Law on Animal Protection. (2007). http://www.uradni-list.si/1/content?id=80271, Uradni list Republike Slovenije no.43/2007, Accesed on 2008-04-26

Lebret, B. (2008). Effects of feeding and rearing systems on growth, carcass composition and meat quality in pigs. Animal, Vol.2, No.10, pp.1548-1558, ISSN 1751-7311

Lebret, B.; Juin, H.; Noblet, J.; \& Bonneau, M. (2001). The effects of two methods for increasing age at slaughter on carcass and muscle traits and meat sensory quality in pigs. Animal Science, Vol.72, pp.87-94, ISSN: 1525-3163

McFarlane, J. M.; \& Cunningham, F. (1993). Environment: Proper ventilation is key to top performance. Veterinary Scope, Vol.3, pp.6-9 ISSN: 0378-1135

Ni, J. Q.; Vinckier, C.; Coenegrachts, J.; \& Hendriks, J. (1999). Effect of manure on ammonia emission from a fattening pig house with partly slatted floor. Livestock Production Science, Vol.59, pp. 25-31, ISSN: 0301-6226

Olsen, A. W.; Dybkjær, L.; \& Simonsen, H. B. (2001). Behaviour of growing pigs kept in pens with outdoor runs II. Temperature regulatory behaviour, comfort behaviour and dunging preferences. Livestock Production Science, Vol.69, pp.265-278, ISSN 0301-6226

Philippe, F. X.; Laitat, M.; Canart, B.; Vandenheede, M.; \& Nicks, B. (2007). Comparison of ammonia and greenhouse gas emissions during the fattening of pigs, kept either on fully slatted floor or on deep litter. Livestock Science, Vol.111, pp.144-152, ISSN: 1871-1413

Quiniou, N.; Noblet, J.; van Milgen, J.; \& Dourmad, J. Y. (1995). Effect of energy intake on performance, nutrient and tissue gain and protein and energy utilization in growing boars. Animal Science, Vol.61, pp.133-43, ISSN 15253163

Verstegen, M. W. A.; Siegerink, A.; Van der Hel, W.; Geers, R.; \& Brandsma, C. (1987). Operant supplementary heating in groups of growing pigs in relation to air velocity. Journal of Thermal Biology, Vol.12, No.4, pp.257-261, ISSN 0306-4565

Weary, D. M.; Jasper, J.; \& Hötzel, M. J. (2008). Understanding weaning distress. Applied Animal Behaviour Science, Vol.110, pp.24-41, ISSN 0168-1591

Wood, J. D.; Brown, S. N.; Nute, G. R.; Whittington, F. M., Perry, A. M., Johnson, S. P.; \& Enser, M. (1996). Effects of breed, feed level and conditioning time on the tenderness of pork. Meat Science Vol.44, pp.105-112., ISSN: 0309-1740 